and

\title{
Achievement goals, the classroom environment, and reflective thinking: A conceptual framework
}

\author{
Huy P. Phan
}
School of Education, The University of the South Pacific, Suva

\section{Republic of Fiji Islands}

Huy P. Phan. Educational Psychology \& Research Methods, Faculty of Arts and Law, School of Education. USP, Laucala Campus, Suva. Republic of Fiji Islands. E-mail: phan_h@usp.ac.fj

(C) Education \& Psychology I+D+i and Editorial EOS (Spain) 


\begin{abstract}
Introduction: Research pertaining to achievement goals and reflective thinking practice has received considerable attention in educational psychology. However, very few, if any, studies have looked at the impact of the classroom climate and how this psychosocial milieu may influence students' engagement in achievement goals and reflective thinking practice in learning.
\end{abstract}

Objectives: This research tested a structural model that included three theoretical frameworks: the classroom environment, achievement goals (mastery, performance-approach, performance-avoidance), and reflective thinking practice. In particular, achievement goals and reflective thinking practice are postulated to act as mediators between the classroom environment and academic performance.

Method: The sample included 298 (142 boys, 156 girls) Year 12 students from four different secondary schools. Causal modeling procedures were used to test and evaluate the mediating and direct influences between the three theoretical frameworks mentioned and academic performance. Likert-type inventories (College and University Classroom Environment Inventory (CUCEI); Reflective Thinking Questionnaire (RTQ); Achievement goals inventories) were administered to students in intact classes.

Results: Path analysis indicated the predictive effects of different facets of the classroom learning environment on mastery and performance (approach, avoidance) goals, and the four phases of reflection. Mastery and performance (approach, avoidance) goals also exerted direct effects on the four phases of reflection. The antecedents of academic performance included students' involvement and performance-approach goals. A one-way MANOVA showed no statistically significance between boys and girls.

Discussion: The evidence ascertained accentuates the important argument that psychosocial milieu of the classroom contributes to students' achievement goal orientations and their engagement in reflective thinking practice.

Keywords: Reflective thinking, classroom environment, achievement goals, secondary school students

Received: 21/05/08 Initial Acceptance: 25/05/08 Definitive Acceptance: 27/06/08 


\section{Resumen}

Introducción: La investigación sobre el logro de objetivos y la práctica del pensamiento reflexivo ha recibido una considerable atención desde la Psicología Educativa. Sin embargo, sólo algunos estudios han prestado atención al impacto que el clima de aula y el ambiente psicosocial tienen sobre ambos.

Objectivos: El estudio evalúa un modelo estructural que formado por tres estructuras teóricas: el ambiente de clase, el logro de objetivos (profundo, enfoque de ejecución, enfoque de evitación) y la práctica del pensamiento reflexivo. Particularmente, el logro de objetivos y la práctica reflexiva se postulan como mediadores entre el ambiente de clase y el rendimiento académico.

Método: La muestra está compuesta por 298 estudiantes de 12 años (142 niños y 156 niñas) de cuatro escuelas de secundaria. Para evaluar la mediación e influencia entre las tres estructuras mencionadas y el rendimiento académico se utilizaron procedimientos de modelado causal. Inventarios tipo Likert (College and University Classroom Environment Inventory, CUCEI); Reflective Thinking Questionnaire (RTQ); Inventario de logros) fueron administrados.

Resultados: El análisis indica los efectos predictivos de las diferentes dimensiones del ambiente de aprendizaje en el aula sobre el dominio y la ejecución de logro, así como las cuatro fases del pensamiento reflexivo. Los objetivos del enfoque profundo y de ejecución también presentan efectos directos sobre las fases de reflexión. El análisis MANOVA no indica diferencias entre hombres y mujeres.

Discusión: Los datos confirman la evidencia de que el ambiente psicosocial del aula afecta a las orientaciones de logro de los estudiantes y su vínculo con la práctica del pensamiento reflexivo.

Palabras clave: Pensamiento reflexive, clima de aula, logro, secundaria 


\section{Introduction}

The psychosocial milieu of the classroom has received considerable research interest over the past two decades. Researchers have explored the classroom environment as a potent mediator of various motivational variables, as well as an antecedent of academic performance outcome (Dorman, Fraser \& McRobbie, 1997; Fraser, 1986). That the classroom environment is an important mediator and determinant of academic performance outcome is evident from the extensive research studies that have been conducted in Australia, the United States, The Netherlands, and Singapore (Khine \& Chiew, 2001). We extend the classroom environment research with the inclusion of achievement goals and the practice of reflection in this study. The main focus of our research involves, in particular, the amalgamation of three theoretical frameworks (classroom environment, achievement goals, and reflective practice) within one study. We use causal modelling procedures to test the direct and indirect effects of the classroom milieu, achievement goals, and reflective thinking practice on students' academic performance.

\section{Theoretical background}

The conceptual model developed in this study, as shown in Figure 1, proposed the interrelations between the classroom environment, achievement goals (involving mastery, performance-approach, performance-avoidance), reflective practice (involving reflection, critical thinking), and academic performance. The psychosocial milieu of the classroom emphasises a number of aspects, important amongst them being the physical, psychological and interpersonal environments, as well as teachers' existing attitudes and behaviours in a classroom (Rana \& Akbar, 2007). Furthermore, the classroom environment has also been referred to as a space or place where there is dynamic participation and interaction between teachers and stu- 
dents, and that there is usage of tools and information resources to pursue and facilitate different learning activities (Wilson, 1996). Research investigation into the classroom environment has resulted in the development of different classroom environment scales; for example, the Learning Environment (Anderson \& Walberg, 1974), the Classroom Environment Scale (Moos \& Trickett, 1974), the Individualised Classroom Environment Questionnaire (Rentoul \& Fraser, 1979), and the College and University Classroom Environment Inventory (Fraser, Treagust, \& Dennis, 1986).

The development of the various classroom environment inventories has resulted in studies that explored the contribution of the classroom climate in predicting students' academic success (Baek \& Hye-Jeong, 2002; Lizzio, Wilson, \& Simons, 2002; Wong \& Watkins, 1998). Furthermore, the work of John Biggs (1989), in particular, involving the $3 \mathrm{P}$ theoretical model (presage, process, and product) has made substantial ground in the study of students' approaches to their learning (SAL) within the context of the classroom environment. In this analysis, research has in general explored the concerted relations between SAL and academic performance, taking into account the importance of the classroom environment (Lizzio et al., 2002; Nijhuis, Segers, \& Gijselaers, 2007; Wong \& Watkins, 1998). Research investigating classroom environment shows that various components of the home environment contribute to the prediction of academic success. For example, Rana and Akbar's (2007) study of Pakistani university students showed various factors of classroom learning environment (including instructional effectiveness, teacher-student interaction, students' attraction for learning, task orientation and students' collaboration) predicted effective learning. In a study involving university students of different faculties (including humanities, business, commerce, environmental sciences, computing sciences, etc) Lizzio et al. (2002) found that positive perceptions of the teaching environment predicted both academic achievement and qualitative learning 
outcomes. Likewise, in a study involving Hong Kong university students Wong and Watkins (1998) found perceptions of an enjoyable classroom led to better mathematics achievement.

The theoretical contention concerning the possible effects of the classroom environment on achievement goals arises from research studies that examined goal structures (Urdan, 2004; Urdan, Kneisel, \& Mason, 1999). The notion of goal structures refers to messages that are conveyed from the environment (e.g., classrooms) to make certain goals salient (Ames, 1992; Urdan, 2004). Achievement goal theory has emerged as a dominant theoretical framework for studying motivation and competence in academic achievement (Dweck \& Leggett, 1988; Harackiewicz, Barron, Tauer, Carter, \& Elliot, 2000). The dichotomous framework of achievement goals, namely mastery and achievement goals (Dweck \& Leggett, 1988; Wolters, Yu, \& Pintrich, 1996), has extended recently to a trichotomous model that includes mastery, performance-approach and performance-avoidance goals (Elliot \& Harackiewicz, 1996; Harackiewicz, Barron, Pintrich, Elliot, \& Trash, 2002). The differentiation between these three types of goals may be explained in the context of students' learning. Students orientating towards mastery goals are interested in acquiring new skills and improving their competence even in the face of obstacles. Performance-approach goals, in contrast, refer to students striving to demonstrate normatively high ability, whereas performance-avoidance goals emphasise students' avoidance of normative incompetence. Each of these three types of goals encompasses specific patterns of cognition, affect, and behaviour. Mastery goals, for example, are related to positive learning behaviours such as the preference for challenging work (Ames \& Archer, 1988; Elliot \& Dweck, 1988), persistence in the face of setbacks (Elliot \& Dweck, 1988), intrinsic motivation for learning (Meece, Blumfeld, \& Hoyle, 1988; Stipek \& Kowalski, 1989), and the use of deep study processing (Ames \& Archer, 1988; Meece et al., 1988). Performance-approach goals have been shown to relate to a number of adapting learning behaviours, such as higher aspiration, absorption during task engagement, 
and performance attainment (Elliot, McGregor, \& Gable, 1999). Performance-avoidance goals, in contrast, are related negatively with intrinsic motivation (Elliot \& Harackiewicz, 1996), an unwillingness to seek help, poor academic performance, and the use of surface study processing (Elliot \& Church, 1997). Finally, research into achievement goals suggests that there are contrasting effects on academic performance between mastery and achievement goals. For example, mastery goals and performance-approach goals are found to relate positively with academic performance (e.g., Dupeyrat \& Mariné, 2005; Fenollar Román, \& Cuestas, 2007), whereas performance-avoidance goals are negatively related to performance (Elliot \& McGregor, 1999).

Research into goal structures suggests that students' orientation towards a particular goal type (e.g., mastery) is influenced, in part, by instructional policies and practices that are set at a school level. In this analysis, the nurturing of achievement goal structure occurs when teachers use normative evaluation practices with an emphasis on ability differences amongst students. In contrast, a mastery goal structure is more salient when teachers encourage and recognise students for mastering specific concepts and skills (Ames, 1992). Furthermore, this line of reasoning suggests that a stronger emphasis on a mastery goal structure in classrooms leads students to have positive affect with an increase in self-efficacy and academic achievement (Urdan, 2004; Urdan \& Midgley, 2003). Similarly, classrooms that are perceived as lacking in a mastery goal structure lead to negative outcome patterns. Collectively, the evidence presented from this area of inquiry advocates the nurturing of classrooms that emphasise on a mastery goal structure. We extend this theoretical contention by arguing that the classroom environment may accentuate a number of facets (e.g., personalisation) that could lead to the adoption of a particular goal orientation (e.g., mastery goal). In essence, the uniqueness of this research investigation lies in our attempt to verify whether a friendly learning climate, for example, may lead students to orientate towards a particular goal type. Like- 
wise, under what learning conditions encouraged in classrooms would result in the adoption of performance-approach or performance-avoidance goals? This argument aligns closely to research studies that have attested to the importance of the classroom environment in facilitating particular learning strategies (Dart, Burnett, Boulton-Lewis, Campbell, Smith, \& McCrindle, 1999; Lizzio et al., 2002; Nijhuis et al., 2007; Wong \& Watkins, 1998).

Another important area of research that is included in our study is the notion of reflective practice. The term reflective practice, or "reflective thinking", may be credited to the work of John Dewey (1933), who defined it as "active, persistent, and careful consideration of any belief or supposed form of knowledge in the light of the grounds that support it and the conclusion to which it tends" (p. 9). In educational psychology, research interest has emerged in the study of reflective thinking practice as possible antecedents of future academic performance (Phan, 2007, 2008). In particular, research pertaining to reflective thinking practice has extended to encompass the work of Jack Mezirow $(1991,1998)$ in transformative education. Leung and Kember (2003), based on Mezirow's theoretical framework, advocate that reflective thinking practice may be categorised into four distinct phases; in their order of importance - habitual action, understanding, reflection, and critical thinking. Habitual action is a mechanical and automatic activity that is performed with little conscious thought. Understanding is learning and reading without relating to other situations. Reflection concerns active, persistent and careful considerations of any assumptions or beliefs grounded in our consciousness. Finally, critical thinking is considered as a higher level of reflective thinking that involves us becoming more aware of why we perceive things, the way we feel, act and do.

Research has shown that, in general, the four phases of reflective thinking practice make a contribution to the prediction of academic performance; for example, habitual action and understanding are related negatively with academic performance (Phan, 2007, 2008), whereas reflection and critical thinking positively predict academic performance (Phan, 
2008). Another finding in reflective thinking research concerns the effects of achievement goals on the four phases of reflection. In a recent study involving tertiary students, Phan (2008) found from path analysis that mastery goals exerted direct positive effects on understanding, reflection, and critical thinking. Performance-approach and performance-avoidance goals and work-avoidance goals also exerted indirect effects on understanding and reflection, but not habitual action or critical thinking.

Similar to the theoretical contention made previously, we also postulate the possible relationship between the classroom environment and the practice of reflection. We argue that an enjoyable classroom environment, for example, may contribute to students' overall engagement in reflection. There are reasons to believe from the limited evidence found at present that an enjoyable and active classroom environment would influence students to engage more in self-reflective thinking and learning. The work of Young (2005) involving university students indicates that an environment filled with supportive feedback and clear set objectives increases students' use of self-regulated strategies. These strategies include organisation, elaboration, and critical thinking. This finding seems to suggest then, that there is a warranted relationship between the classroom environment and students' engagement in reflective thinking.

Given the importance of achievement goals and reflective thinking practice, it is important to note that there is limited research at present discerning the relationship between these two constructs with secondary school students. Extending this research inquiry to secondary school children is needed as there are reasons to believe that similar findings may be reported. The work of Phan $(2007,2008)$ has, for example, produced evidence attesting to tertiary students' reflective thinking practice and achievement goal orientations. Very little is known, however, about students of earlier ages. Furthermore, similar to the work of Wong and Watkins (1998), research is warranted to explore mathematics as this is considered as a 
hard core subject. Investigating mathematics performance may, for instance, provide more fruitful information into the complex process of reflective thinking practice in a particular classroom environment. Previous research cited has focused predominantly in the humanities subjects such as Human Development and Educational Psychology (Phan, 2007, 2008).

\section{The Present Study}

In light of the evidence presented, a conceptual framework is developed to explore two major foci: (i) the possible effects of the classroom environment on achievement goals, reflective thinking practice, (2) the direct and indirect effects of achievement goals and reflective thinking practice on academic performance. We extend the research inquiry by incorporating two separate theoretical orientations (achievement goals and reflective thinking), which are seen as antecedents of academic performance, within one study. In particular, our examination of the classroom context and its possible effects on achievement goals, reflective thinking, and academic performance is made in a multi-classroom context. The classroom milieu explored in previous research studies has been contextualised predominantly in Western and Eastern sociocultural contexts (Baek \& Hye-Jeong, 2002; Dart et al., 1999; Lizzio et al., 2002; Wong \& Watkins, 1998).

In exploring the classroom environment, we used the College and University Classroom Environment Inventory (CUCEI) developed by Fraser et al. (1986). This inventory is unique as it captures seven facets of the classroom environment - Personalisation, Involvement, Student Cohesiveness, Satisfaction, Task Orientation, Innovation, and Individualisation. The descriptions for each scale and sample items are shown in Table 1. Furthermore, the scales are developed based on Moos' s (1974) three categories of dimensions for conceptualising all human environments; in this case, Relationship Dimensions (the nature and intensity of personal relationships), Personal Development Dimensions (basic directions along which 
personal growth and self-enhancement tend to occur), and System Maintenance and System

Change Dimensions (extent to which the environment is orderly, clear in expectation, maintains control and is responsive to change).

Table 1. Descriptive information for each scale of CUCEI ${ }^{1}$

\begin{tabular}{|c|c|c|c|}
\hline Scale name & $\begin{array}{c}\text { Moos } \\
\text { category }\end{array}$ & Scale description & Sample items \\
\hline Personalisation & $\mathrm{R}$ & $\begin{array}{l}\text { Emphasis on opportunities } \\
\text { for individual students to } \\
\text { interact with the lectur- } \\
\text { er/tutor and on concern for } \\
\text { students' personal welfare. }\end{array}$ & $\begin{array}{l}\text { The lecturer goes } \\
\text { out of his/her way } \\
\text { to help students } \\
(+)\end{array}$ \\
\hline Involvement & $\mathrm{R}$ & $\begin{array}{l}\text { Extent to which students } \\
\text { participate actively and at- } \\
\text { tentively in class discussion } \\
\text { and activities. }\end{array}$ & $\begin{array}{l}\text { The lecturer dom- } \\
\text { inates class dis- } \\
\text { cussions (-) }\end{array}$ \\
\hline $\begin{array}{l}\text { Student cohesive- } \\
\text { ness }\end{array}$ & $\mathrm{R}$ & $\begin{array}{l}\text { Extent to which students } \\
\text { know, help and are friendly } \\
\text { towards each other. }\end{array}$ & $\begin{array}{l}\text { Students in this } \\
\text { class get to know } \\
\text { each other well } \\
(+)\end{array}$ \\
\hline Satisfaction & $\mathrm{R}$ & $\begin{array}{l}\text { Extent of enjoyment of clas- } \\
\text { ses. }\end{array}$ & $\begin{array}{l}\text { This class is a } \\
\text { waste of time (-) }\end{array}$ \\
\hline Task orientation & $\mathrm{P}$ & $\begin{array}{l}\text { Extent to which class activi- } \\
\text { ties are clear and well organ- } \\
\text { ised. }\end{array}$ & $\begin{array}{l}\text { Getting a certain } \\
\text { amount of work } \\
\text { done is important } \\
\text { in this class }(+)\end{array}$ \\
\hline Innovation & $\mathrm{S}$ & $\begin{array}{l}\text { Extent to which the lectur- } \\
\text { er/tutor plans a new, unusual } \\
\text { class activities, teaching } \\
\text { techniques and assignments. }\end{array}$ & $\begin{array}{l}\text { New and different } \\
\text { ways of teaching } \\
\text { are seldom used } \\
\text { in this class (-) }\end{array}$ \\
\hline Individualisation & $\mathrm{S}$ & $\begin{array}{l}\text { Extent to which students are } \\
\text { allowed to make decisions } \\
\text { and are treated differentially } \\
\text { according to ability, interest } \\
\text { or rate of working }\end{array}$ & $\begin{array}{l}\text { Students are gen- } \\
\text { erally allowed to } \\
\text { work at their own } \\
\text { pace }(+)\end{array}$ \\
\hline
\end{tabular}

${ }^{1}$ Note: Adapted from Fraser et al. (1986, p. 48). R = Relationship dimension, P: Personal development dimension, S: System maintenance and System change dimension. Items designated (+) are scored 7, 6, 5, 3, 2, 1 respectively, for the responses Strongly Agree, Agree, Disagree and Strongly Disagree. Items designated (-) are scored in the reverse manner. Omitted or invalid responses are scored 4. 
In the present study, we chose to use four of the seven scales of the CUCEI (Fraser et al., 1986); these four scales are: Involvement, Satisfaction, Task Orientation, and Student Cohesiveness. The other three scales were not included as they do not, in our view, reflect the characteristics of the classroom environment in this context. We have developed our conceptual model, shown in Figure 1, based on existing research evidence where four hypotheses are postulated:

[HP1]: The four components (scales) of the classroom environment are hypothesised to influence achievement goals (including mastery, performance-approach, and performanceavoidance), reflective thinking practice, and academic performance directly. This hypothesis reflects previous research studies that indicate associations between the classroom environment and reflective thinking (Young, 2005) and academic performance (Lizzio et al., 2002; Nijhuis et al., 2007; Rana \& Akbar, 2007). The postulation is concerned with the possible association between the classroom environment and different achievement goals.

[HP2]: Mastery goals, consistent with Phan's (2008) study, are hypothesised to exert positive effects on understanding, reflection, and critical thinking. In contrast, performanceapproach and performance-avoidance goals are hypothesised to influence habitual action and understanding, but not reflection or critical thinking.

[HP3]: In line with previous research studies (Dupeyrat \& Mariné, 2005; Fenollar et al., 2007), we postulate that mastery and performance-approach goals would exert positive effects on academic performance. In contrast, performance-avoidance goals are hypothesised to exert a negative effect on academic performance (Elliot \& McGregor, 1999).

[HP4]: Recent research conducted also allows us to make postulations in relation to the four phases of reflection and academic performance. The importance of the four phases of reflective thinking practice to relate to each other in a unidirectional manner is reflected in 
Phan's $(2007,2008)$ studies. For example, it is argued that earlier phase of reflection (i.e., habitual action) would form the basis for the formation and development of the later phases (i.e., understanding $\rightarrow$ reflection). Further analysis also indicates salient paths between the four phases of reflection and academic performance. Specifically, it is hypothesised that habitual action and understanding would exert negative effects on academic performance and, in contrast, positive effects are exerted for reflection and critical thinking.

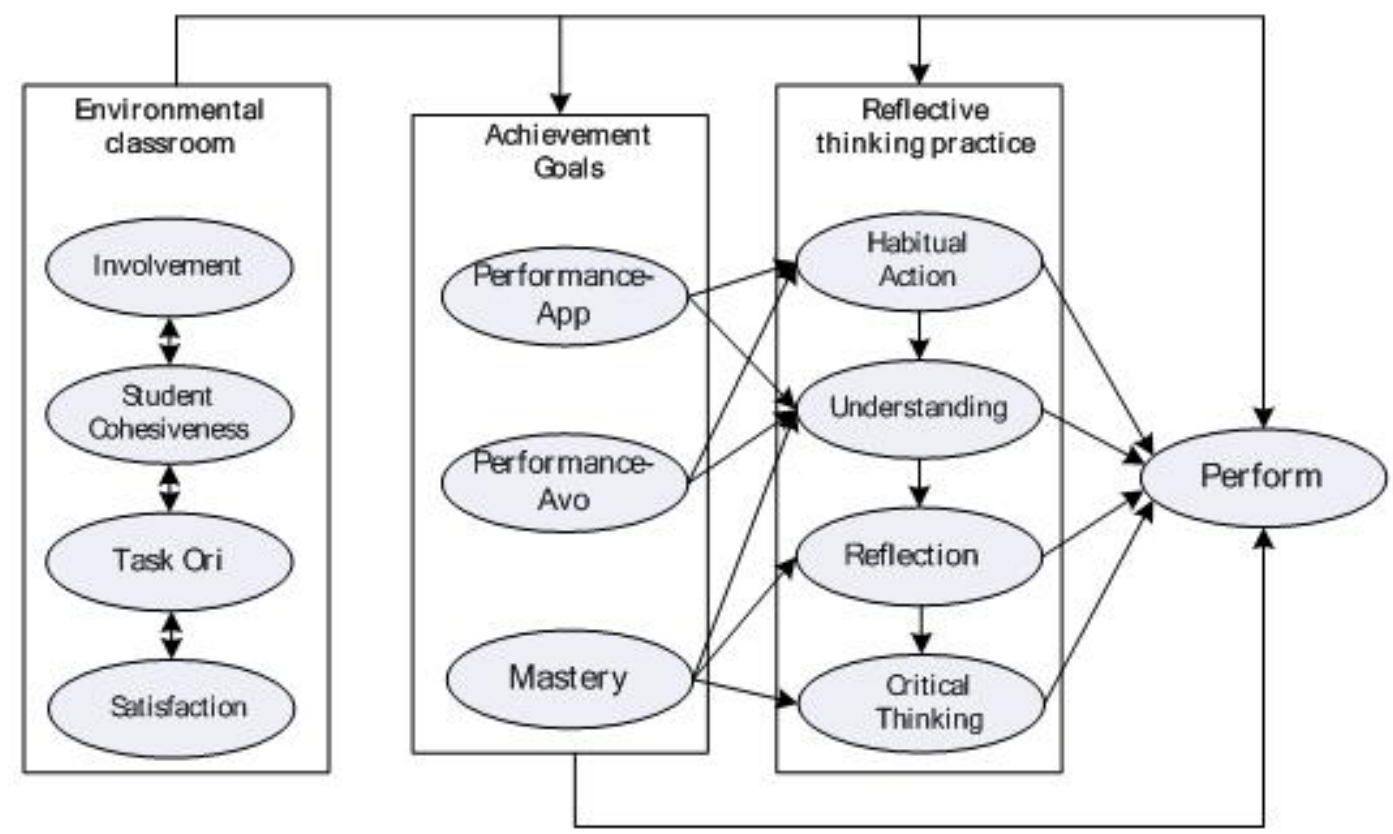

Figure 1. A conceptual model involving the classroom environment, achievement goals, reflective thinking practice, and academic performance. Note: Task ori $=$ task orientation, Performance-app $=$ performance-approach goals, Per-avo $=$ performance-avoidance goals, Mastery $=$ mastery goals.

In summary, research findings pertaining to relationships between the classroom environment and academic performance, and achievement goals and academic performance are consistent and clear. Similarly, it would seem that the evidence concerning the four phases of reflective thinking and academic performance is logical and in accordance with existing theoretical contentions. Much less is known, however, about the relations between the classroom environment and its possible effects on achievement goals and reflective thinking practice. 
Evidence we obtain from the present study may help to strengthen and elucidate the status concerning the impact of the classroom environment on students' achievement goals, and the engagement in reflective thinking practice.

\section{Method}

\section{Participants}

A sample of 298 (142 boys, 156 girls) secondary school students was drawn from 4 secondary schools in Sydney, Australia. The ages of the students ranged from 16 to 18 (mean $=17.86$ years). All students attended Year 12, the highest class level for secondary schools in Sydney. The instruments were administered in intact classes with the assistance of a research assistant. Participation by the students was voluntary and no remuneration was offered. Students were also instructed to write down their names for the purpose of collecting their overall performance marks in mathematics. Students were assured of anonymity and were informed why their overall performance marks in mathematics were needed.

\section{Instruments}

Participants were all given an information booklet that contained a questionnaire with items descriptive of the classroom environment, mastery and achievement goals, and reflective thinking practice. Participants were required to respond on a 7-point Likert-type rating scale $(1=$ strongly disagree to $7=$ strongly agree). Mastery goals, performance-approach goals, and performance-avoidance goals were measured with Midgley, Kaplan, Middleton, Maehr, Urdan, Anderman, Anderman, and Roeser's (1998) 5-item scales. The items include, for example: “An important reason why I do my academic work is because I like to learn new things" (mastery goal); "It's important to me that the other students in my classes think that I 
am good at my work" (performance-approach goal); and "It's very important to me that I don't look stupid in my classes" (performance-avoidance goal).

Reflective thinking was measured using the Kember, Leung, Jones, Loke, McKay, Sinclair, Tse, Webb, Wong, Wong, and Yeung (2000) 16-item Reflective Thinking Questionnaire (RTQ). The sample items include, for example: "In this course we do things so many times that I started doing them without thinking" (Habitual action); "To pass this course you need to understand the content" (Understanding); "I often re-appraise my experience, so I can learn from it and improve for my next performance" (Reflection); and "This course has challenged some of my firmly held ideas" (Critical thinking).

Various components of the classroom environment were measured from the 49-item scale (College and University Classroom Environment Inventory (CUCEI)) developed by Fraser et al. (1986). As indicated previously, only four of the seven scales were used in this study. The sample items include, for example: "The teacher dominates class discussions" (Involvement), "Students in this class get to know each other well" (Student cohesiveness), "This class is a waste of time" (Satisfaction), and "Getting a certain amount of work done is important in this class" (Task orientation) ${ }^{1}$.

Finally, academic performance was measured by collating students' overall marks in mathematics at the end of the school term. Cronbach's alpha indicated reliability estimates of .59 for the performance-approach scale, .81 for the performance-avoidance scale, and .80 for the mastery scale. The reliability estimates ranged from .62 to .64 for the four subscales of the RTQ (.62 for Habitual action, .64 for Understanding, and .65 for Reflection, and .64 for Critical thinking), and from .70 to .82 for the four subscales of the CUCEI (.82 for Involvement, .73 for Student Cohesiveness, .70 for Task orientation, .76 for Satisfaction). It is noted that the reliability estimates for the four subscales of the RTQ reported here are similar to those 
values mentioned in previous research studies (e.g., Phan, 2007, 2008). The moderate reliability estimates found in this study may reflect the small number of items (4) within each subscale.

\section{Data analysis and results}

Path analysis was used to explore the interrelations between the variables hypothesised in Figure 1. Path analysis is a statistical method that enables examination of both direct and indirect effects of independent variables on dependent variables (Cook \& Campbell, 1979). Although criticisms have not gone unnoticed, path analysis is still considered as a significant technique as it allows us to test different a priori and a posteriori models based on strong empirical evidence and theoretical grounding. In this study, we used the statistical softwares SPSS 15 and LISREL 8.72 - to analyse the data. Covariance matrices were computed from raw data and subsequently analysed using the maximum likelihood (ML) method. This estimation procedure was chosen as it has been shown to perform reasonably well with multivariate normally distributed data (Chou \& Bentler, 1995). The three indexes chosen as indicators representative of a well-fitted model include the comparative fit index $(C F I)$, the goodness of fit index $(G F I)$, and the root mean square of approximation (RMSEA). Models with $C F I$ and GFI values close to .95 and $R M S E A$ values less than .50 are normally considered an acceptable fit.

The correlational matrix and means and standard deviations are presented in Table 2, and statistically significant paths are shown in the model in Figure 2. The model yielded a $G F I=.93$, a $C F I=.85$, and a $R M S E A$ of $.15-$ all indicative of relatively good fit indexes. The direct and indirect effects on academic performance are presented in Table 3. Overall, the model accounted for $9 \%$ of the variance in academic performance, and $33 \%, 17 \%, 12 \%, 31 \%$,

\footnotetext{
${ }^{1}$ The wordings of some items have been changed to suit the context of secondary schools; for example, the use of 'teacher' and not 'lecturer' or 'tutor'.
} 
$9 \%, 19 \%$ and $14 \%$ of the variances in critical thinking, reflection, understanding, habitual

action, mastery, and performance-avoidance and performance-approach goals, respectively.

Table 2. Correlation matrix of $\mathrm{X}$ and $\mathrm{Y}$ in path analytical model

\begin{tabular}{|c|c|c|c|c|c|c|c|c|c|c|c|c|c|c|}
\hline & M & SD & App & Avoi & Mast & HA & $\mathbf{U}$ & $\mathbf{R}$ & CR & Aca & Inv & Coh & Sat & Tas \\
\hline App & 5.38 & 1.36 & 1.00 & & & & & & & & & & & \\
\hline Avoi & 5.14 & 1.01 & .16 & 1.00 & & & & & & & & & & \\
\hline Mast & 5.16 & 1.14 & .11 & .12 & 1.00 & & & & & & & & & \\
\hline HA & 5.16 & 1.09 & .43 & .24 & .13 & 1.00 & & & & & & & & \\
\hline $\mathbf{U}$ & 5.75 & .94 & -.11 & -.13 & .11 & -.07 & 1.00 & & & & & & & \\
\hline $\mathbf{R}$ & 3.46 & 1.31 & .12 & .14 & .15 & .18 & .02 & 1.00 & & & & & & \\
\hline CR & 5.67 & .91 & .19 & .20 & .29 & .25 & -.01 & .32 & 1.00 & & & & & \\
\hline Aca & 61.26 & 11.05 & .16 & .00 & -.10 & .10 & -.08 & -.05 & .06 & 1.00 & & & & \\
\hline Inv & 3.76 & 1.61 & .16 & .08 & .11 & .14 & .23 & .00 & .20 & -.12 & 1.00 & & & \\
\hline Coh & 6.02 & .85 & .27 & .30 & .20 & .38 & -.16 & .29 & .32 & -.01 & -.04 & 1.00 & & \\
\hline Sat & 5.91 & .81 & .32 & .40 & .26 & .38 & -.13 & .35 & .46 & -.01 & .07 & .47 & 1.00 & \\
\hline Tas & 6.29 & .79 & .18 & .17 & .15 & .35 & -.12 & .33 & .39 & .09 & .00 & .46 & .50 & 1.00 \\
\hline
\end{tabular}

Note: $\mathrm{M}=$ mean, $\mathrm{SD}=$ standard deviation, App $=$ Performance-approach goal, Avoi $=$ Performanceavoidance goal, Mast $=$ mastery goal, $\mathrm{HA}=$ habitual action, $\mathrm{U}=$ understanding, $\mathrm{R}=$ reflection, $\mathrm{CR}$ $=$ critical thinking, Aca $=$ academic performance in mathematics, Inv $=$ involvement, $C o h=$ student cohesiveness, Sat $=$ satisfaction, Tas $=$ task orientation.

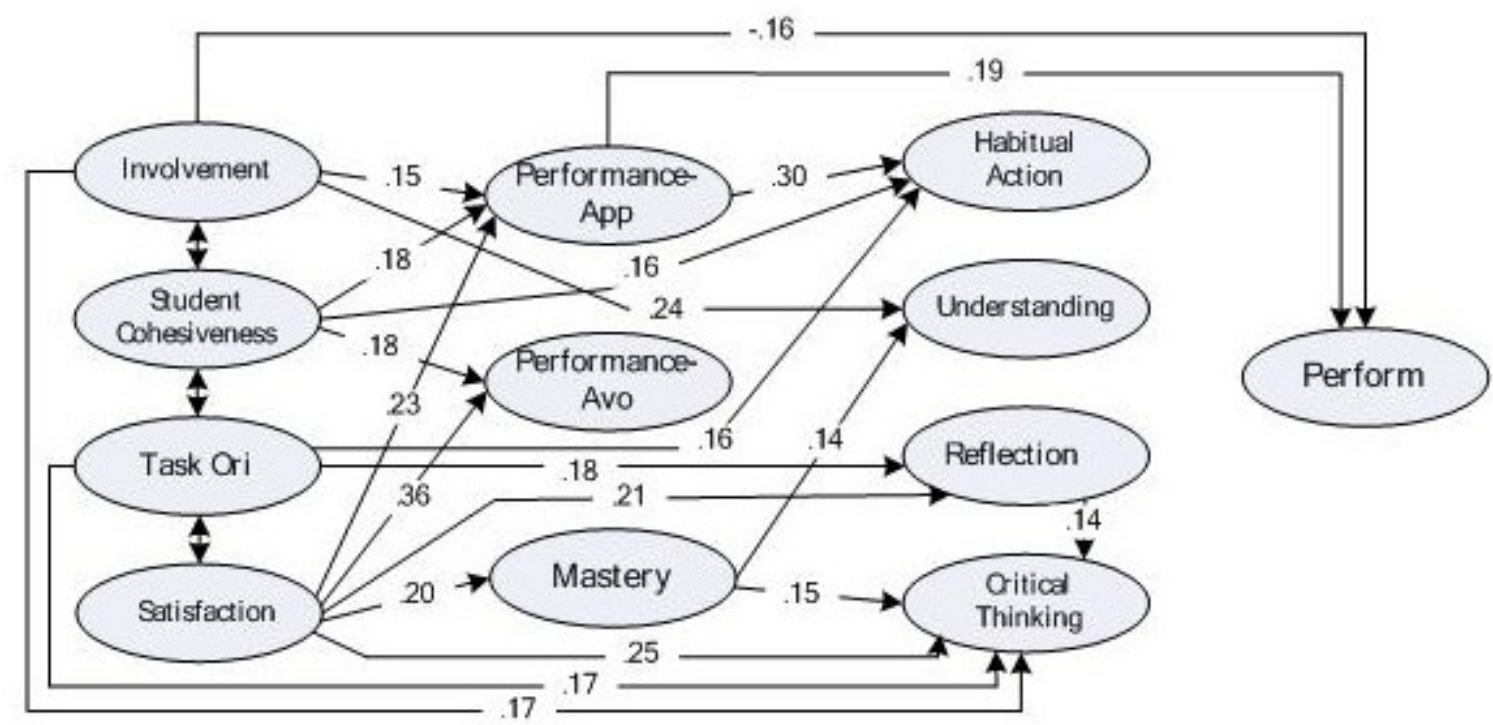

Figure 2. A full structural model involving the classroom environment, achievement goals, reflective thinking practice, and academic performance. Given the complexity of the original hypothesized model, nonsignificant paths have been omitted for clarity. Note: Task ori $=$ task orientation, Performance-app $=$ performance-approach goals, Per-avo $=$ performance-avoidance. 
Table 3. Direct, indirect, and total effects of path model

\begin{tabular}{|c|c|c|c|c|c|c|}
\hline \multirow{2}{*}{$\begin{array}{l}\text { Effect } \\
\text { On performance }\end{array}$} & \multicolumn{2}{|c|}{ Direct } & \multicolumn{2}{|c|}{ Indirect } & \multicolumn{2}{|c|}{ Total } \\
\hline & & & & & & \\
\hline - Of critical thinking & .13 & & - & & .13 & \\
\hline - Of reflection & -.09 & & .02 & & -.07 & \\
\hline - Of understanding & -.02 & & -.01 & & -.03 & \\
\hline - Of habitual action & .07 & & .00 & & .07 & \\
\hline - Of performance-app & .19 & $* *$ & .02 & & .21 & $* *$ \\
\hline - Of performance-avoid & .02 & & .01 & & .03 & \\
\hline - Of mastery & -.11 & & .01 & & -.10 & \\
\hline - Of involvement & -.16 & $* *$ & .05 & & -.11 & \\
\hline - Of student cohesive & -.11 & & .04 & & -.07 & \\
\hline - Of task-orientation & .13 & & .02 & & .15 & \\
\hline - Of satisfaction & -.11 & & .07 & & -.04 & \\
\hline \multicolumn{7}{|l|}{ On critical thinking } \\
\hline - Of reflection & .14 & $*$ & - & & .14 & $*$ \\
\hline - $\quad$ Of understanding & - & & .01 & & .01 & \\
\hline - Of habitual action & - & & .00 & & .00 & \\
\hline - Of performance-app & - & & .00 & & .00 & \\
\hline - Of performance-avoid & - & & .00 & & .00 & \\
\hline - Of mastery & .15 & $* *$ & .01 & & .16 & $* *$ \\
\hline - Of involvement & .17 & $* *$ & .01 & & .18 & $* *$ \\
\hline - Of student cohesive & .06 & & .03 & & .09 & \\
\hline - Of task-orientation & .17 & $* *$ & .02 & & .19 & $* *$ \\
\hline - Of satisfaction & .25 & $* *$ & .06 & $* *$ & .31 & $* *$ \\
\hline \multicolumn{7}{|l|}{ On reflection } \\
\hline - $\quad$ Of understanding & .09 & & - & & .09 & \\
\hline - Of habitual action & - & & .00 & & .00 & \\
\hline - Of performance-app & - & & -.01 & & -.01 & \\
\hline - Of performance-avoid & - & & -.01 & & -.01 & \\
\hline - Of mastery & .04 & & .01 & & .05 & \\
\hline - Of involvement & -.04 & & .03 & & -.01 & \\
\hline - Of student cohesive & .11 & & -.01 & & .10 & \\
\hline - Of task-orientation & .18 & $* *$ & .00 & & .18 & $*$ \\
\hline - Of satisfaction & .21 & $* *$ & .00 & & .21 & $* *$ \\
\hline \multicolumn{7}{|l|}{ On understanding } \\
\hline - Of habitual action & .01 & & & & .01 & \\
\hline - Of performance-app & -.11 & & .00 & & -.11 & \\
\hline - Of performance-avoid & -.10 & & .00 & & -.10 & \\
\hline - Of mastery & .14 & $*$ & - & & .14 & $*$ \\
\hline - Of involvement & .24 & $* *$ & -.01 & & .23 & $* *$ \\
\hline - Of student cohesive & -.08 & & -.02 & & -.10 & \\
\hline - Of task-orientation & -.04 & & .01 & & -.03 & \\
\hline - Of satisfaction & -.06 & & -.03 & & -.09 & \\
\hline \multicolumn{7}{|l|}{ On habitual action } \\
\hline - Of performance-app & .30 & $* *$ & - & & .30 & $* *$ \\
\hline - Of performance-avoid & .07 & & - & & .07 & \\
\hline - Of mastery & - & & - & & - & \\
\hline - Of involvement & .09 & & .05 & $*$ & .14 & $*$ \\
\hline - Of student cohesive & .16 & $*$ & .07 & $*$ & .23 & $* *$ \\
\hline - Of task-orientation & .16 & $*$ & -.01 & & .15 & $*$ \\
\hline - Of satisfaction & .10 & & .10 & $* *$ & .20 & $* *$ \\
\hline \multicolumn{7}{|l|}{ On Performance-approach } \\
\hline - Of involvement & .15 & $* *$ & - & & .15 & $* *$ \\
\hline - Of student cohesive & .18 & $* *$ & - & & .18 & $* *$ \\
\hline - Of task-orientation & -.01 & & - & & -.01 & \\
\hline - Of satisfaction & .23 & $* *$ & - & & .23 & $* *$ \\
\hline \multicolumn{7}{|l|}{ On Performance-avoidance } \\
\hline - Of involvement & .06 & & - & & .06 & \\
\hline - Of student cohesive & .18 & $* *$ & - & & .18 & $* *$ \\
\hline - Of task-orientation & -.09 & & - & & -.09 & \\
\hline
\end{tabular}




\begin{tabular}{cccccc}
$\bullet \quad$ Of satisfaction & .36 & $* *$ & - & .36 & $* *$ \\
On Mastery & & & - & .10 & \\
$\bullet \quad$ Of involvement & .10 & - & .12 & \\
$\bullet \quad$ Of student cohesive & .12 & - & .00 & \\
$\bullet \quad$ Of task-orientation & .00 & & - & .20 & $* *$ \\
\hline$\quad$ Of satisfaction & .20 & $* *$ & - & - \\
\hline
\end{tabular}

Note: $* t<1.996,{ }^{* *} t<2.556$.

The two direct effects on academic performance were performance-approach goals $(\beta$ $=.19)$ and involvement $(\beta=-.16)$. Only performance-approach goals exerted a total effect on academic performance $(\beta=.21)$. In relation to the classroom environment and the four phases of reflection, the total effects statistically significant on critical thinking included satisfaction $(\beta=.31)$, task orientation $(\beta=.19)$, and involvement $(\beta=.18)$. For reflection, the strongest total effect was satisfaction $(\beta=.21)$ followed by task orientation $(\beta=.18)$. The strongest total effect on habitual action was student cohesiveness $(\beta=.23)$, followed by satisfaction ( $\beta$ $=.20)$, task orientation $(\beta=.15)$, and then involvement $(\beta=.14)$. For understanding, only involvement exerted a significant total effect on academic performance $(\beta=.23)$. The various components of the classroom environment also influenced critical thinking and habitual action directly. Critical thinking was influenced indirectly by satisfaction $(\beta=.06)$, whereas habitual action was influenced indirectly by satisfaction $(\beta=.10)$, student cohesiveness $(\beta=$ $.07)$, and involvement $(\beta=.05)$.

In relation to the classroom environment and achievement goals, only satisfaction exerted a direct effect on mastery goals $(\beta=.20)$, and performance-approach $(\beta=.23)$ and performance-avoidance $(\beta=.36)$ goals. Student cohesiveness also exerted a direct effect on performance-approach $(\beta=.18)$ and performance-avoidance $(\beta=.18)$ goals. Finally, only performance-approach goals were influence directly by $(\beta=.15)$. With the relations between achievement goals and the four phases of reflective thinking practice, mastery goals exerted direct positive effects on critical thinking $(\beta=.15)$ and understanding $(\beta=.14)$, whereas ha- 
bitual action was influenced directly by performance-approach goals $(\beta=.30)$. Finally, the results also indicated the influence of reflection on critical thinking $(\beta=.14)$. No other direct or indirect effects were observed between the four phases of reflection.

As a subsidiary analysis, we noted some differences in the mean scores between boys and girls with reference to mastery and achievement goals, the four phases of reflective thinking, and academic performance. We performed a one-way multivariate analysis of variance to determine if there were potential gender differences. Eight dependent variables were used: mastery and achievement (approach, avoidance) goals, the four phases of reflection, and academic performance. The independent variable was gender. Preliminary assumption was conducted to ensure for normality, linearity, univariate and multivariate outliers, and no violations were noted. To avoid Type I error, a Bonferroni correction of $p<.006$ was applied. Levene's tests showed that the assumption of equal variance of all variables had been met ( $p$ $>.05)$. The results indicated statistically significant difference between males and females on the combined dependent variables, $F(8,260)=2.15, p=.03$, Wilk's $\lambda=.94 ; \eta^{2}=.06$. When the results for the dependent variables were considered separately using the adjusted alpha's value, no statistical significance was observed. This non-significance is similar to previous research studies (Phan, 2007, 2008) that also showed no significant gender differences in achievement goals, reflective thinking practice, and academic performance.

\section{Discussion}

The classroom environment has been featured as an important characteristic in students' learning outcomes and the study processing strategies in which they engage. Review of the literature suggests that there is an absence of research concerning the relationship between the classroom environment and the practice of reflection and achievement goals. The purpose of the current study therefore was to include mastery and achievement goals (Ames, 1992; 
Elliot et al., 1999; Elliot \& Dweck, 1988) and reflective thinking practice (Leung \& Kember, 2003; Mezirow, 1991; Phan, 2007) within the theoretical framework of the classroom environment. In particular, we used the CUCEI (Fraser et al., 1986) to explore the various classroom environment components and their concerted influences on achievement goals, reflection, and academic performance. Equally important to this study is the mediating mechanism of achievement goals and reflective thinking practice.

Data drawn from secondary school students indicated, in general, that the four components of the classroom environment - involvement, student cohesiveness, task orientation, and satisfaction (Fraser et al., 1986) - exerted direct and indirect influences on achievement goals, reflective thinking practice, and students' academic performances in mathematics. Furthermore, consonant with existing theoretical overviews, both achievement goals and reflective thinking practice are found to act as potent mediators and antecedents of academic performance. In relation to the classroom environment and academic performance, involvement was the only component to exert a negative effect on students' academic performance outcomes in mathematics. The more students participate actively in classroom discussion and activities, the less likely they are to perform successfully in mathematics. There is, in our view, a strong collective feeling expressed to resist classroom discussion and/or activities. In essence, this line of argument may extend to the subject discipline itself, where mathematics is very much perceived as a subject that requires independent 'text-book' problem solving. Teaching and learning pedagogies (including classroom discussion and activities) that conflict with students' own personal philosophies and upbringing in learning a particular subject may, in fact, affect their academic sucess. Perhaps, given this perplexity, it is not surprising to find students perform poorly when faced with learning activities that differ from their own cultural beliefs and values. 
In terms of the classroom environment and reflective thinking practice, the evidence we obtain shows that the existing classroom psychosocial milieu facilitates the development of reflective thinking. Task orientation and satisfaction are perceived as distinctive facets that influence critical thinking, reflection, and habitual action. Likewise, involvement is perceived by students as an important feature in the forming and engagement of critical thinking, understanding, and habitual action. This finding seems to support our earlier hypothesis and the work of Young (2005) in accentuating the important relationship between the classroom environment and reflective thinking practice. The perception of an enjoyable classroom climate where learning activities are clear and organised is prevalent, according to students, in instilling a mindset that knowledge, in general, may be acquired for different reasons and purposes. The engagement in knowledge attainment may simply be to recall facts and information, or it could involve the generation of hypothesis with a critical review for further improvement. In essence, students' purposes and dictations for fulfilling specific learning objectives may be served by an environment that fosters active participation and classroom discussion. At the highest level of learning, students become more aware and critical of their own learning when in an enjoyable classroom environment they are encouraged to participate actively in classes, and teachers on their part present clear and organised lesson plans and teaching. At the other extreme, the need to acquire knowledge for recall of facts and information occurs when there is a sense of knowing and friendliness amongst students (student cohesiveness). The consensus perhaps is that a sharing of friendly disposition amongst students may result more in companionship rather than actual academic learning.

In terms of the classroom environment and achievement goals, our findings are unique in noting the effects of the classroom environment on students' achievement goals. The perception of an enjoyable classroom climate results in mastery goals. This finding, when compared with previous studies in goal structures (Urdan, 2004; Urdan et al., 1999) and deep 
study processing strategies (Lizzio et al., 2002; Nijhuis et al., 2007; Wong \& Watkins, 1998) may not come as a surprise. A classroom setting that is non-competitive and non-threatening instills to students a mastery goal structure, wherein they are more motivated and grounded in the need to acquire and master new skills and knowledge. Non-competitive and nonthreatening situations occur when teachers are less inclined to show a tendency towards normative evaluation practices. Despite this line of reasoning, an enjoyable classroom environment also results in students adopting both performance-approach and performance-avoidance goals. This finding would seem to suggest then, that the adoption of different achievement goals is affected by an enjoyable classroom climate. By the same token, the adoption of performance-approach and performance-avoidance goals is affected by student cohesiveness. The extent to which students know, help and are friendly towards each other is instrumental in the facilitation of performance-approach and/or performance-avoidance achievement goals. One could argue perhaps, that students learn collectively from their classroom association and copy each other's habits and approaches. Furthermore, the sharing of personal beliefs, expectations, and motivation amongst students may further guide in the orientation of a particular goal type.

The involvement that takes place in classroom learning also influences students to orientate towards performance-approach goals. Performance-approach goal orientation may be explained from the context of classroom learning. For example, when evaluation practices and competition are made salient by students in a group discussion or class activities, there is then a strong emphasis in a performance-goal structure. Receiving cues from others, unquestionably, will lead many students to construe the importance of succeeding and surpassing others in their learning.

Evidence ascertained in this study also supports previous findings concerning the relationship between achievement goals and the four phases of reflection. Mastery goals, con- 
sistent with the work of Phan (2008), are found to relate positively with critical thinking and understanding. There is a tendency for students who pursue mastery goals to engage instinctively in critical thinking and, in part, understanding, as these two reflective phases are prevalent in facilitating the development of skill improvement and the acquiring of knowledge and factual contents. The need to achieve task mastery and to improve competence in learning is needed to help students engage in a critical examination and analysis of their learning. In contrast, performance-approach goals relate more with habitual action. Students espousing the need and motivation to achieve and to succeed would approach learning in a superficial manner. This premise would seem to support the theoretical groundings of performance-approach goals (Elliot \& McGregor, 1999; Elliot et al., 1999) and reflection (Leung \& Kember, 2003; Mezirow, 1991; Phan, 2007) in terms of their objectives.

Performance-approach goals, in line with existing evidence (Elliot \& McGregor, 1999), were found to predict students' academic performance outcomes in mathematics. Similar to previous studies also (Dupeyrat \& Mariné, 2005; Fenollar et al., 2007; Phan, 2008), there was a non-significant relation between mastery goals and academic performance. The relationships established may be explained from the context of alignment between assessment and learning outcome. For example, it has been argued that misalignment in teaching and learning outcomes often results in students not fulfilling their learning objectives or meeting the appropriate criteria (Biggs, 1999; Phan, 2007). Subsequently, it is often the case an emphasis on mastery learning or a mastery goal structure is not reflected from classroom evaluation and assessment criteria. Mastery learning cannot be captured and reflected from assessment tasks that emphasise recall of information and memorisation. One could argue that the motivation and the need to achieve and to surpass others, academically, may only be met when assessment criteria and tasks reflect normative evaluation practices; for example, the use of multiple-choice exams where marks are ranked accordingly. This postulation could 
also explain why there is an absence of statistical significance in the relationship between the four phases of reflection and academic performance. For example, previous research studies conducted by Phan $(2007,2008)$ show a positive effect of critical thinking, and negative effects of habitual action and understanding on academic performance.

The present findings provide limited support for the four phases of reflection. The phase reflection was found to predict critical thinking. This evidence is important as it supports previous theoretical contentions and hypotheses that the early phase of reflection (i.e., habitual action) forms the basis for the development of later phases (e.g., reflection) (Phan, 2007, 2008). In essence, the complexity of the reflection and critical thinking phases require the forming of the two earlier phases. This line of inquiry is still in its infancy, and more research studies using different methodological means are needed to explore the formation of reflective thinking practice. Qualitative methodological approaches, for example, may provide more enriching information into the underlying process of reflection and how the four phases are interrelated.

Evidence obtained from the current study also accentuates the mediating mechanism involved in achievement goals. The findings show, in particular, the potent role of mastery and performance-approach goals as mediators between the classroom environment and critical thinking and habitual action. Mastery goals were found to mediate the effect of satisfaction on critical thinking, whereas involvement, student cohesiveness, and satisfaction influenced habitual action via performance-approach goals. This line of examination differs from previous research studies (Elliot et al., 1999; Fenollar et al., 2007; Phan, 2008) that showed different achievement goals as antecedents of various motivational variables and academic performance. In contrast, however, we found that reflective thinking practice did not mediate relations between the classroom environment and achievement goals and academic performance. Previous research studies (Phan, 2007, 2008) have reported that reflective thinking practice 
acts, in general, as a mediator between achievement goals, various motivational variables (e.g., self-efficacy), study processing strategies and academic performance. Strong emphasis on the mediating mechanism of achievement goals and reflective thinking practice suggests and warrants further research insight and investigation into this issue.

Attempts to explore the relations between achievement goals and reflective thinking practice in the context of the classroom environment are still preliminary. The importance of our research study lies in its theoretical contribution towards the classroom environment and how this may influence achievement goals and the engagement in reflective thinking practice. Furthermore, evidence obtained from this study illustrates, in general, various facets of the secondary classroom milieu and how they influence students' academic learning. To a certain extent, the small absence thereof in findings relating to the classroom environment, achievement goals, and reflective thinking practice suggests the need for further research studies in this area. Methodologically, the use of longitudinal data in conjunction with causal modelling procedures serves as a better premise for inferring causation. For example, future research could clarify and provide confirmation to the question of whether mastery goals cause an engagement in reflection and critical thinking. Likewise, do performance-approach and performance-avoidance goals cause an engagement in habitual action and understanding? The same argument may also apply to the possible causal influence of the home environment on achievement goals, reflective thinking practice, and academic performance. Furthermore, one could extend the issue of causation to cause-and-effect relationships between reflective thinking practice and achievement goals (e.g., mastery). In this analysis, the work of Barker (2007) has explored the reciprocity between achievement goals, self-concept, and academic achievement. The same argument may also apply to the causal and reciprocal relations between reflective thinking practice and goal orienations (e.g., mastery). The postulation concerns whether reflective thinking may, in fact, operate as a determinant of mastery goals or, 
alternatively, a product of mastery goals. Students' ability to engage in reflection and critical thinking may, subsequently, lead to a preference and orientation for mastery learning and skill improvement. A preference and orientation towards mastering competence and learning may also cause students to develop skills that could help in the formation of reflective thinking practice.

Another methodological approach that has featured in motivational research involves the use of triangulation (Creswell, 2003; Tashakkori \& Teddlie, 2003). The work of Urdan (2004) involving goal structures, for example, used both quantitative and qualitative approaches. A qualitative approach may in fact provide more enriching information concerning the underlying complex process of achievement goals. The classroom dynamism and how it features in students' repertoire of learning may be explored, for example, from naturalistic observation (Elmes, Kantowitz, \& Roediger, 2006; McBurney \& White, 2007). Such a qualitative procedure would provide an alternative insight into the psychosocial milieu of the classroom, especially from a researcher's perspective and interpretation. Further qualitative analysis may provide additional information into the classroom climate and its underlying process in affecting learning.

In conclusion, this research study is significant in providing a conceptual model that connects different theoretical frameworks together. In particular, different facets of the classroom environment are depicted to relate to students' achievement goal orientations and reflective thinking practice. Academic performance was found, in particular, to be influenced by two constructs, namely involvement and performance-approach goal orientation.

The author would like to thank the two anonymous reviewers, whose suggestions have helped to make this article more articulated. 


\section{References}

Ames, C. (1992). Classrooms: Goals, structures, and student motivation. Journal of Educational Psychology, 84, 261-271.

Ames, C. \& Archer, J. (1988). Achievement goals in the classroom: Students' learning strategies and motivation processes. Journal of Educational Psychology, 80, 260-267.

Anderson, G. J. \& Walberg, H. J. (1974). Learning environments. In H. J. Walberg (Ed.), Evaluating Educational Performance: A sourcebook of methods, instruments, and examples. Berkeley, CA: McCutchan.

Baek, S-G. \& Hye-Jeong, C. (2002). The relationship between students' perceptions of classroom environment and their academic achievement in Korea. Asia Pacific Education, 3(1), $135-135$.

Barker, K. (2007). Students' goals, academic self-concept and academic achievement: Testing competing models of causation. A refereed article for the Australian Association for Research in Education, Fremantle, Western Australia, Australia.

Biggs, J. (1989). Approaches to the enhancement of tertiary teaching. Higher Education Research and Development, 8, 7-25.

Biggs, J. (1999). Teaching for quality learning at university. Buckingham, UK: SRHE and Open University Press.

Chou, C. P. \& Bentler, P. M. (1995). Estimates and tests in structural equation modeling. In R. H. Hoyle (Ed.), Structural equation modeling: Concepts, issues, and application, pp. 3755. Thousand Oaks, CA: Sage.

Cook, T. D. \& Campbell, D. T. (1979). Qualitative-experimentation: Design and analysis issues for field settings. Boston, MA: Houghton Mifflin.

Creswell, J. W. (2003). Research design: Qualitative, quantitative, and mixed methods approaches $\left(2^{\text {nd }}\right.$ ed). Thousand Oaks: Sage. 
Dart, B., Burnett, P., Boulton-Lewis, G., Campbell, J., Smith, D., \& McCrindle, A. (1999). Classroom learning environments and students' approaches to learning. Learning Environments Research, 2(2), 137-156.

Dewey, J. (1933). How we think. Chicago: Henry Regnery.

Dorman, J. P., Fraser, B. J., \& McRobbie, C. J. (1997). Relationship between school-level and classroom-level environments in secondary schools. Journal of Educational Administration, 35(1), 74-91.

Dupeyrat, C. \& Mariné, C. (2005). Implicit theories of intelligence, goal orientation, cognitive engagement, and achievement: A test of Dweck's model with returning to school adults. Contemporary Educational Psychology, 30, 43-59.

Dweck, C. S. \& Leggett, E. L. (1988). A social-cognitive approach to motivation and personality. Psychological Review, 95, 256-273.

Elliot, A. J. \& Church, M. A. (1997). A hierarchical model of approach and avoidance achievement motivation. Journal of Personality and Social Psychology, 72, 218-232.

Elliot, A. J. \& Harackiewicz, J. M. (1996). Approach and avoidance achievement goals and intrinsic motivation: A mediational analysis. Journal of Personality and Social Psychology, $70,461-475$.

Elliot, A. J. \& McGregor, H. A. (1999). Test anxiety and the hierarchical model of approach and avoidance achievement motivation. Journal of Personality and Social Psychology, 76(4), 628-644.

Elliot, A. J., McGregor, H. A., \& Gable, S. L. (1999). Achievement goals, study strategies, and exam performance: A mediational analysis. Journal of Educational Psychology, 76, 628644.

Elliot, E. S. \& Dweck, C. S. (1988). Goals: An approach to motivation and achievement. Journal of Personality and Social Psychology, 54, 5-12.

Elmes, D. G., Kantowitz, B. H., \& Roediger, H. L. (2006). Research methods in psychology ( $8^{\text {th }}$ ed.). Belmont, CA: Thomson Wadsworth. 
Fenollar, P., Román, S., \& Cuestas, P. J. (2007). University student's academic performance: An integrative conceptual framework and empirical analysis. British Journal of Educational Psychology, 77, 873-891.

Fraser, B. J. (1986). Classroom environment. London: Croom Helm.

Fraser, B. J., Treagust, D. F., \& Dennis, N. C. (1986). Development of an instrument for assessing classroom psychosocial environment at universities and colleges. Studies in Higher Education, 11, 43-54.

Harackiewicz, J. M., Barron, K. E., Pintrich, P. R., Elliot, A. J., \& Trash, T. M. (2002). Revision of achievement goal theory: Necessary and illuminating. Journal of Educational Psychology, 94, 638-645.

Harackiewicz, J. M., Barron, K. E., Tauer, J. M., Carter, S. M., \& Elliot, A. J. (2000). Shortterm and long-term consequences of achievement goals: Predicting interest and performance over time. Journal of Educational Psychology, 92(2), 316-330.

Kember, D., Leung, D., Jones, A., Loke, A. Y., McKay, J., Sinclair, K., Tse, H., Webb, C., Wong, F. K. Y., Wong, M. \& Yeung, E. (2000). Development of a questionnaire to measure the level of reflective thinking. Assessment and Evaluation in Higher Education, 25, 381-389.

Khine, M. S. \& Chiew, G. S. (2001). Investigation of tertiary classroom learning environment in Singapore. Paper presented at the International Educational Research Conference, Australian Association for Educational Research (AARE). University of Notre Dame, Fremantle, Western Australia, $2^{\text {nd }}-6^{\text {th }}$ December 2001.

Leung, D. Y. P. \& Kember, D. (2003). The relationship between approaches to learning and reflection upon practice. Educational Psychology, 23(1), 61-71.

Lizzio, A., Wilson, K., \& Simons, R. (2002). University students' perceptions of the learning environment and academic outcomes: Implications for theory and practice. Studies in Higher Education, 27(1), 27-52.

McBurney, D. H. \& White, T. L. (2007). Research methods ( $7^{\text {th }}$ ed.). Belmont, CA: Thomson Wadsworth. 
Meece, J. L., Blumenfeld, P. C., \& Hoyle, R. H. (1988). Students' achievement goals and cognitive engagement in classroom activities. Journal of Educational Psychology, 80, 514523.

Mezirow, J. (1991). Transformative dimensions of adult learning. San Francisco CA: JosseyBass.

Mezirow, J. (1998). On critical reflection. Adult Education Quarterly, 48, 185-198.

Midgley, C., Kaplan, A., Middleton, M., Maehr, M. L., Urdan, T., Anderman, L. H., Anderman, \& Roeser, R. (1998). The development and validation of scales assessing students' achievement achievement goals. Contemporary Educational Psychology, 23, 113-131.

Moos, R. H. (1974). The social Climate Scales: An overview. Palo Alto, CA: Consulting Psychologists Press.

Moos, R. H. \& Trickett, E. J. (1974). Classroom Environment Scale Manual. Palo Alto, CA: Consulting Psychologists Press.

Nijhuis, J., Segers, M., \& Gijselaers, W. (2007). The interplay of perceptions of the learning environment, personality and learning strategies: A study amongst International Business Studies students. Studies in Higher Education, 32(1), 59-77.

Ninnes, P. (1991). Culture and learning in Western Province, Solomon Islands. MA thesis, Flinders University, Western Australia.

Phan, H. P. (2007). Examination of student learning approaches, reflective thinking, and selfefficacy beliefs at the University of the South Pacific: A path analysis. Educational Psychology, 27(6), 789-806.

Phan, H. P. (2008). Unifying different theories of learning: Theoretical framework and empirical evidence. Educational Psychology, 28(3), 325-340.

Rana, R. A. \& Akbar, R. A. (2007). Relationship between classroom learning environment and students' achievement in higher education.

http://www.apqn.org/events/past/details/103/presentations/files/03 relationship between clas sroom learning_environment.pdf, created $2^{\text {nd }}$ May 2007, downloaded $22^{\text {nd }}$ August 2007. 
Rentoul, A. J. \& Fraser, B. J. (1979). Conceptualization of enquiry-based or open classroom learning environments. Journal of Curriculum Studies, 11, 233-245.

Stipek, D. J. \& Kowalski, P. S. (1989). Learned helplessness in task-orienting versus performance-orienting test conditions. Journal of Educational Psychology, 81, 384-391.

Tashakkori, A. \& Teddlie, C. (2003). Handbook of mixed methods in social and behavioural research. Thousand Oaks: Sage.

Urdan, T. (2004). Using multiple methods to assess students' perceptions of classroom goal structures. European Psychologist, 9(4), 222-231.

Urdan, T., Kneisel, L., \& Mason, V. (1999). Interpreting messages about motivation in the classroom: Examining the effects of achievement goal structures. In T. Urdan (Ed.), Advanced in Motivation and Achievement, Vol 11. Stamford, CT: JAI.

Urdan, T. \& Midgley, C. (2003). Changes in the perceived classroom goal structure and patterns of adaptive learning during adolescence. Contemporary Educational Psychology, 28, 524-551.

Wilson, B. G. (1996). Introduction: What is a constructivist learning environment? In B. G. Wilson (Ed.), Constructivist learning environments, pp. 3-8. Englewood Cliffs, NJ: Educational Technology Publications.

Wolters, C. A., Yu, S. L., \& Pintrich, P. R. (1996). The relation between goal orientation and students' motivational beliefs and self-regulated learning. Learning and Individual Differences, 6, 211-238.

Wong, N-Y. \& Watkins, D. (1998). A longitudinal study of the psychosocial environmental and learning approaches in the Hong Kong classroom. Journal of Educational Research, 91(4), 247-254.

Young, M. R. (2005). The motivational effects of the classroom environment in facilitating self-regulated learning. Journal of Marketing Education, 27(1), 25-40. 